\title{
Weronika GROCHOWICKA
}

\section{PATRIOTYZM W KAZANIACH GRIGORA PYRLICZEWA}

\section{Patriotism in Grigor Parlichev's Sermons}

Keywords: Grigor Parlichev, Bulgarian language, Greek language, hellenisation, Greek patriarchate, Bulgarian eparchy, sermons, patriotism

Contact: Uniwersytet im. Adama Mickiewicza w Poznaniu; weronika.grochowicka@gmail.com

Druga połowa XIX wieku to okres przełomowy dla Bałkanów, decydujący o ich historii ze względu na ówczesny układ sił międzynarodowych, intensywne ruchy narodowowyzwoleńcze i nowe zjawiska kulturowe. To między innymi także czas walki o bułgarską Cerkiew i szkołę w zrozumiałym, narodowym języku. Celem referatu jest ukazanie działalności Grigora Pyrliczewa, jednego z najważniejszych bułgarskich budzicieli narodowych, który w czasach odrodzenia narodowego przyczynił się swoją aktywnością do rozwoju szkolnictwa w języku bułgarskim i opowiadał się za utworzeniem bułgarskiego egzarchatu. Żeby Cerkiew i szkoły miały szanse zaistnieć w języku bułgarskim, musiał podnieść świadomość narodową Bułgarów, wychowywanych dotąd i kształconych przez grecką szkołę i grecki Kościół, w wyniku czego często "zapominali" o swojej własnej tożsamości etnicznej albo ją tracili w ogóle. Byli przyzwyczajeni do używania języka greckiego w codziennym życiu i nie odczuwali szczególnej potrzeby sprecyzowania swojej narodowej samoidentyfikacji.

Podstawowym narzędziem Pyrliczewa służącym do przeprowadzania akcji budzicielskiej są jego kazania ${ }^{1}$, wygłaszane w bułgarskich szkołach, cerkwiach czy publikowane w gazetach. Zanim zostaną poddane analizie, należy krótko przybliżyć dzieje Cerkwi, szkolnictwa i sytuacji językowej na terenach dziewiętnastowiecznej Bułgarii.

\footnotetext{
${ }^{1}$ Analizie poddałam kazania Grigora Pyrliczewa, które powstawały od lat 60. do 80. XIX wieku. Współcześnie zebrane zostały w zbiorze: Г. Пърличев, Григор Пърличев. Избрани произведения, София, 1980. Korzystałam $z$ wersji elektronicznej (skany stron $z$ książki), dostępne $z$ : http:/www.promacedonia.org/gps/ pyrlichev_3_publitsistika.pdf(2020-02-27).
} 
Po opanowaniu kraju przez Turków autokefaliczny Kościół bułgarski został zlikwidowany i w pełni poddany patriarchatowi w Konstantynopolu, który wprowadził nabożeństwa w języku greckim. Grecy zaczęli zajmować większość stanowisk duchownych (przede wszystkim wyższe stopnie w hierarchii). Większość szkół prowadzona była przez Greków, co wydatnie ograniczało, a niekiedy wykluczało możliwości kształcenia w języku słowiańskim (Floryan 1991: 45). Niektórzy bułgarscy działacze odrodzeniowi proponowali nawet, by językiem literackim uczynić grekę. Pomysł ten popierało stronnictwo hellenofilów, czyli etnicznych Bułgarów, mówiących po grecku, wychowanych przez greckie szkoły i wspierających patriarchat Konstantynopola z powodów ekonomicznych, społecznych czy zawodowych (Floryan 1991: 67). Na rzecz patriarchatu wierni płacili wysokie podatki - i nierzadko oskarżali jego przedstawicieli o nadużycia władzy, korupcję czy pijaństwo (Detrez 2010: 66-67, 74).

Sytuacja wyznaniowa w Bułgarii zaczęła się zmieniać w latach 30. XIX wieku, gdy pod wpływem idei Wielkiej Grecji i dominacji Greków w Kościele oraz hellenizacji liturgii (Dąbek-Wirgowa 1980: 62) wywiązał się konflikt między klerem greckim a słowiańskim, co zainicjowało religijny ruch separacyjny, stanowiący zaczątek bułgarskiego ruchu narodowowyzwoleńczego dążącego do zachowania tożsamości narodowej (Simeonova-Konach 2010: 260). W latach 70. XIX wieku nastąpiło oddzielenie się Cerkwi bułgarskiej od Konstantynopola i utworzono tzw. egzarchat bułgarski przy wsparciu tureckim - ferman sułtana Abdülaziza z 1870 roku (Temelski 2003: 206-217).

Równolegle $\mathrm{z}$ tendencjami narodowowyzwoleńczymi oraz ruchem autonomizacji Kościoła aktywizowała się działalność oświatowo-kulturowa, będąca dziełem bułgarskiej inteligencji, duchowieństwa i mieszczaństwa (Simeonova-Konach 2010: 276). W latach 30. i 40. wzmaga się ruch szkolny, którego podstawą było rozpowszechnianie wiedzy w języku ojczystym. To czas publikacji pierwszych podręczników i książek do nauki gramatyki bułgarskiej (Drzewiecka 2016: 230). Poza tym greckim szkołom zaczęły towarzyszyć szkoły grecko-słowiańskie i greckobułgarskie, wreszcie całkowicie zrezygnowano z greckiego szkolnictwa, rozwijając szkoły narodowe ze zrozumiałym (tzn. nie cerkiewnosłowiańskim) językiem nauczania (Dąbek-Wirgowa 1980: 72,74). Od połowy XIX wieku prężnie rozwijał się oświatowy ruch czytelniczy, skupiony wokół czytelni ludowych (Czekalski 2010: 16-17). Książki dla potrzeb oświaty z konieczności drukowano poza bułgarskimi granicami, przede wszystkim w Rumunii i Rosji.

Warto wspomnieć, iż w procesie odrodzenia narodowego i rozwoju oświaty na Bałkanach aktywnie wykorzystywano idee słowianofilskie, zaszczepione 
przedstawicielom elit kulturowych głównie w Rosji, stanowiącej serce emigracji młodzieży bułgarskiej (Floryan 1991: 51). Wracająca do ojczyzny młodzież oprócz myśli słowianofilskiej przenosiła na własny grunt nowe prądy literackie. Dzięki studentom pojawiały się tłumaczenia literatury rosyjskiej i zachodnioeuropejskiej, co w rezultacie przyczyniło się do podniesienia poziomu literatury rodzimej (Floryan 1991: 59-60).

Grigor Pyrliczew jako jeden z bułgarskich budzicieli narodowych aktywnie bierze udział w rozwijaniu świadomości narodowej Bułgarów. Jego kazania i argumenty w nich zawarte zbudowane są tak, że koncentrują się na wzbudzeniu w słuchaczach niechęci do Greków, greckiego duchowieństwa i grekomanów, jednocześnie wyzwalając miłość do Bułgarii i do jej języka. Pyrliczew wierzy, że tylko wspólne działania przyniosą efekty, dlatego w tak emocjonalny sposób kieruje swoje słowa do braci Bułgarów, ucząc ich patriotycznej postawy.

Budziciel otwarcie mówi o swoim negatywnym stosunku do greckiego patriarchatu, stawiając jego przedstawicieli w opozycji do Turków, którzy wykazują się wobec ludności słowiańskiej większą tolerancją:

Osmanowie ani razu nie drwili $\mathrm{z}$ naszego języka, ani $\mathrm{z}$ wiary; a patriarchowie greccy zabrali nasz patriarchat i nasz język sprzeniewierzyli, i księgi bułgarskie spalili, i z siłą mamy greckie pieśni śpiewać, i oczy nam zaślepili, i najgorszym z narodów nas uczynili! (Pyrliczew 1980: 208)

Pyrliczew ukazuje swoją nienawiść do patriarchatu, tym samym wylicza przewinienia greckiego kleru - odebranie Bułgarom niezależności kościelnej i narzucenie greckiej mowy przy jednoczesnym okazaniu im pogardy. Potraktowani zostali jak niewolnicy, poddani, którzy nie mogą się wyzwolić.

Pisarz zauważa podłe zachowanie chciwego greckiego duchowieństwa, nadużywającego swojej pozycji. Nie są dobrymi pasterzami chrześcijan ani też nie sprawują dobrze swoich ról. Nie stanowią wzoru skromności, pobożności, a nawet ascezy tak, jak Jezus Chrystus:

Zatem oto biskup mówi o wartości wiary i władcy, a wy maluczcy nie zamykacie mu ust nieczystych, i nawet dobrze wiecie, że on sam nie szanuje wiary i nie czyni jak Chrystus. Dlaczego Chrystus nie pobierał majątku, a biskup tak; Chrystus ubierał się biednie, a biskup nosi się ze 
splendorem; Chrystus nakazał apostołom żyć jak asceci - z jedną sutanną, jedną laską drewnianą, $\mathrm{z}$ sandałami, torbą chleba na ramieniu (...) Chrystus płacił podatek na władcę, a biskup łamie prawa władcy; Chrystus dał swą duszę jego owcom, a biskup swoim owcom duszę odebrał (Pyrliczew 1980: 202-203).

Bułgar poddaje się greckiemu biskupowi, ślepo mu służy, choć widzi jego wady, ale nie ma odwagi przeciwstawić się tym zachowaniom. Pyrliczew w tym miejscu wytyka słuchaczom zaślepienie, bezmyślność. Mówi stanowczo i w surowym tonie po to, by wpłynąć na myślenie bułgarskich braci.

Budziciel zauważa, iż Bułgarzy nie potrafią także zrozumieć modlitw w cerkwi, odprawianych w obcym dla nich języku:

Jezus Chrystus mówi: „Ten, który jest spragniony, niech przyjdzie do mnie, a dam mu pić”. Czym jest woda Chrystusa, która gasi pragnienie ludzi? To Pismo Święte. A my, biedni, słyszymy tylko jego imię, ponieważ wybrzmiewa z Pisma Świętego, ale co w Nim jest napisane, pojęcia nie mamy. Śpiewają, a nie rozumiemy, tylko stoimy jak skamieniali (Pyrliczew 1980: 207).

Są narodem pobożnym i religijnym, ale dostęp do zrozumienia Bożego Słowa blokuje bariera językowa. Znaczącym problemem jest więc zaślepienie Bułgarów greką i tym, co greckie. Autor wskazuje na bezmyślne poddaństwo i fałszywe przekonanie o większym prestiżu greckiego języka. Jednocześnie pragnie zwrócić uwagę Bułgarów na język ojczysty, który jest równie piękny jak greka i na pewno bardziej zrozumiały:

Wysyłamy dzieci na naukę greki nie po to, by się czegoś uczyły, ale z zarozumiałości. Gdybyśmy chcieli ich czegoś nauczyć, uczylibyśmy ich języka ojczystego. Nie! Grecki jest bardziej honorowy! Chodzimy tłumnie do cerkwi, nie po to, by cokolwiek zrozumieć, chrzest także przyjmujemy dla samozadowolenia (Pyrliczew 1980: 201).

Wysyłanie dzieci na naukę greki jest surowo potępiane. Najmłodsi uczą się greki, bo chcą tego ich rodzice, a oni sami nie mają z tego żadnego pożytku. 
Dokonuje również krytyki poddańczej postawy bułgarskiego narodu. Łatwo i bez walki poddali się polityce greckiej. Dzieci wysyłane są do szkół na naukę greki, której nie potrafią zrozumieć:

Mamy swój język i go sprzeniewierzyliśmy. Wszystkie narody uczą się swojego języka, a my uczymy się cudzego i najbardziej uciążliwego. Dzieci śpiewają w szkołach, a nic nie rozumieją. Dlatego uczą się bez pasji i pozostają ślepi (Pyrliczew 1980: 207).

Pyrliczew zauważa, że nauka obcego, trudnego języka jest niezwykle męcząca, więc dzieci uczą się greki niechętnie i bezrozumnie. Budziciel chce wstrząsnąć słuchaczami i kładzie nacisk na to, że dzieci nie uczą się ojczystej mowy, a przecież zaczęły już powstawać szkoły uczące narodowego języka. Podkreśla, że greka nie zapewnia postępu, skoro jest trudna do zrozumienia i do nauczenia, więc rodzice muszą zapewnić najmłodszym godne nauczanie ojczystej mowy. Zauważa również, że wszystkie narody kształtują swój narodowy język i nim się posługują, a Bułgarzy pozostają w tyle.

Jest jednak dla nich nadzieja, a tą nadzieją jest nauka. Stanowi lek na ich chore umysły, na zaniedbanie, którego się dopuścili (tamże: 204). Należy wysyłać dzieci do Europy, by mogły zdobywać tam cenne wykształcenie, choć w Bułgarii już zaczęto uczyć bułgarskiego: „Taki przykład mamy w Bułgarii: w czas otworzono szkoły języka narodowego i oświeca się i rozumie dobro i zło"(Pyrliczew 1980: 205).

Bułgarzy zmieniali greckie szkoły na bułgarskie ku niezadowoleniu Greków: „Grecy zastanawiają się, jak zasymilować całe bułgarskie eparchie z całym ich dobytkiem, ale nadal krzyczą i rozdzielają swoje koszule, że Bułgarzy zabrali kościoły i szkoły. W jaki sposób człowiek lub naród może zabrać to, co zawsze było i jest w jego rękach?" (Pyrliczew 1980: 241). Ostatnie zdanie silnie wpływa na słuchaczy i ma rozbudzić w nich patriotyzm - Bułgarzy nie pozwolili i nie pozwolą odebrać sobie tego, co należy do nich.

Patriotyczne wychowanie młodego pokolenia jest niezwykle ważne. Pisarz naucza, że dzieci są niczym biała karta, „co na niej napiszesz, to na niej zostanie” (Pyrliczew 1980: 199). Odpowiedzialność za najmłodszych ponoszą dorośli, zwłaszcza rodzice. Tym samym Pyrliczew podkreśla to, jak bardzo dorosłe pokolenie ma wpływ na młodsze. 
Autor nawołuje do uwielbienia własnej ojczyzny i nauki rodzimego języka, jednocześnie wskazując na trudności związane z przyswajaniem greki i podkreślając użyteczność i łatwość nauczenia się mowy ojczystej:

Na co ci potrzebny rozum, kiedy on ci mówi: „Dbaj o swoją ojczyznę i kochaj ją bardziej od wszystkiego innego!" Na co ci potrzebny rozum, skoro on ci mówi: „Ucz się języka ojczystego, gdyż jest łatwy i oświeci cię w krótkim czasie", a ty się uczysz greki, i nic nie rozumiesz ani w cerkwi, ani w szkole, i ciągle się męczysz, i nie dbasz o siebie, i nie oświecasz się? Mówię ci, że łatwiej jest uczyć się dziesięciu języków europejskich, niż samej greki (Pyrliczew 1980: 200).

Nauka języka greckiego jest niezwykle czasochłonna, a tak długotrwały i męczący proces nie przynosi oczekiwanych rezultatów, daje jedynie ledwie podstawową znajomość greckiej mowy. Wszelkie języki europejskie, będące drzwiami do świata kultury, są łatwiejsze od greki.

Kazanie poświęcone św. Klemensowi również ukierunkowane jest na odrzucenie greki i umożliwienie dzieciom nauki rodzimej mowy. Uczynić to trzeba, mając w sercach miłość do św. Klemensa i jego słowiańskich ksiąg i nauk, bowiem wierzy się, iż święty przybył do Ochrydy ze swoimi książkami, by nauczać i oświecać miejscową pogańską ludność. Jednak w XVIII wieku istniejące tam arcybiskupstwo zamknięto, ludność podporządkowała się władzy Greków, którzy spalili wszelkie możliwe znalezione bułgarskie księgi i nakazali uczyć się greki. Dla Bułgarów nastał znów mrok. Sam Pyrliczew powiedział: „Prawie żaden Bułgar niczego nie mógł się nauczyć. Nawet wstydziliśmy się nazywać Bułgarami; nasze imię było złe. Nazywali nas upartymi” (Pyrliczew 1980: 236). Teraz Pyrliczew udowadnia, że bycie Bułgarem to powód do dumy, dlatego trzeba walczyć o własny język i Cerkiew.

W związku z tym Pyrliczew przekonuje, iż mowa słowiańska jest jednym z języków, którymi można głosić Słowo Boże: „In nova lingua gloriatur nomen domini nostril, tzn. niech Imię Boże będzie sławione w nowym języku. Jak dotąd Imię Boże wysławiano tylko greką i łaciną, a teraz sławi się je w trzecim języku - języku słowiańskim, dźwięcznym, bogatym i świętym” (Pyrliczew 1980: 232). Stawia ją tym samym pośród świętych języków Słowa Bożego. Dokonuje legitymizacji słowiańskiej mowy i udowadnia, że nie jest gorsza od greki, a wręcz przeciwnie — postawiona jest $\mathrm{z}$ nią na równym poziomie.

Pyrliczew wyjaśnia także, iż dzięki rodzimej mowie można sprowadzić duchownych na dobrą drogę. Przeklinanie greckiego biskupa i bunt niczego nie zmieni, 
należy wykorzystać rodzimy język jako narzędzie sprzeciwu, przy okazji wybudzić Bułgarów z letargu i obojętności. To spowoduje, że duchowieństwo podda się jak bezbronne, zagubione jagnię i trafi na właściwą drogę (Pyrliczew 1980: 201). Nawołuje także do zjednoczenia się, by móc przywrócić wspólnymi siłami niezależny patriarchat bułgarski, który stanowiłby dla Bułgarów symbol niezależności religijnej (Pyrliczew 1980: 211).

Patriarchat utworzono w końcu w 1870 roku dzięki dekretowi sułtana. Z tej okazji Pyrliczew wygłosił mowę w cerkwi w Ochrydzie, a towarzyszyło jej wielkie przejęcie oraz łzy wzruszenia. Był to wreszcie ,(...) jasny dzień, wesoły, wielki, święty, radość nad radości, święto nad świętami” (Pyrliczew 1980: 215). Bułgarzy otrzymali to, co zostało im zabrane - poczucie tożsamości narodowej oraz język. Dotąd byli pogardzani i wyśmiewani przez inne narody Skończyło się kościelne poddaństwo greckiemu patriarchatowi. Stanęli na równi z innymi narodami, radowali się, a to wszystko dzięki sułtanowi: „(...) i wszyscy płaczą z radości, tak jak my, gdy płakaliśmy ze smutku, że straciliśmy patriarchę, tak teraz płaczemy z radości, że umarli zostali wskrzeszeni, że to co stracone, znalazło się. Dzieci, chwalcie sułtana! (pieśń)” (Pyrliczew 1980: 216). Kazanie jest nie tylko wyrazem radości z powodu utworzenia Egzarchatu, ale również pochwałą sułtana, wyrażającą wdzięczność Bułgarów.

Grigor Pyrliczew jest uznawany również za jednego z ojców macedońskiej literatury - nie tylko dlatego, że urodził się w Ochrydzie na terenie dzisiejszej Macedonii, ale i przez to, że część badaczy uważa język jego utworów za początkowy literacki język macedoński. Stąd należy wspomnieć o kazaniu poświęconemu obcej propagandzie kulturowej w Macedonii ze strony Grecji i Serbii. Pisarz nawołuje braci Bułgarów do niesienia pomocy Macedończykom:

Bułgarscy bracia! Czy wiecie, co cierpią wasi bracia Macedończycy? Czy wiecie, jaki ogień płonie na ich głowach, ogień rozpalony przez różne propagandy? Naprawdę, w bułgarskich gazetach mówi się o jakimś głosie w Macedonii, ale wydaje mi się, że są całkiem słabi, ponieważ jesteśmy niemal duszeni z każdej ze stron tak, że ledwie są słyszalne nasze głosy do was (Pyrliczew 1980: 238).

Macedończycy co prawda w czasach odrodzenia narodowego rozbudzili poczucie odrębnej tożsamości, jednak w walce przeciwko hellenizacji i obcym propagandom stali po stronie Bułgarów, także ze względu na podobny język i kulturę (Stawowy-Kawka 2000: 133-135). Pyrliczew jednoczy się z Macedończykami i razem z nimi woła o pomoc do Bułgarów: 
Jeden za wszystkich, bracie, posłuchajcie naszego głosu. Macedonia jest w niebezpieczeństwie propagand. Ukrzyżowali ją sami profesorowie i konsulowie i dyrektorzy z Grecji, serbscy nauczyciele i nauczycielki, krzyżują Macedonię i protestujących. Wszyscy składają obietnice i ofiarują nauczycieli, nauczycielki, pieniądze i książki, nawet szkoły (Pyrliczew 1980: 238).

Autor wie, że propaganda ma na celu uzyskanie poddaństwa ludności macedońskiej poprzez narzucenie obcej kultury i języka, bowiem XIX wiek to czas walki o tereny macedońskie. Słowiański obszar Macedonii stał się obiektem rywalizacji między Serbią, Bułgarią i Grecją - była to tzw. kwestia macedońska, dotycząca motywowanych historycznie roszczeń sąsiadów Macedonii wobec jej terytorium i kultury (Stawowy-Kawka 2000: 131).

Pyrliczew wie, że obce wpływy działają niekorzystnie na świadomość macedońską:

Bracia Bułgarzy! I oto jak ze wszystkich stron otoczyły Macedonię obce propagandy; i czy to nie dlatego, że nie mamy dobrych narodowych pasterzy? (Pyrliczew 1980: 239)

Zauważa więc, że uciśnionemu narodowi potrzebni są przewodnicy, budziciele, którzy pozwolą odbudować własną tożsamość narodową.

$\mathrm{Z}$ pełnym przekonaniem można orzec, iż Grigor Pyrliczew zasługuje na miano wybitnego budziciela narodu bułgarskiego. W kazaniach formułował swoje argumenty w taki sposób, by jak najsilniej wpłynąć na myślenie i emocje jego słuchaczy, bułgarskich braci. Wypowiadał się w sposób zdecydowany, mocno podkreślając swoje zdanie i dumnie uświadamiając, że język bułgarski jest równy nie tylko językom nauki, językom Europy, ale jest też mową, w której można głosić Słowo Boga. Miłością do ojczyzny i do rodzimego języka ukazał swój patriotyzm, który wyraźnie pragnął zaszczepić w Bułgarach, zwłaszcza w najmłodszym pokoleniu. Wskazywał na podłości wyrządzane przez Greków, na hellenizację, pozbawiającą ludu ducha narodowego. Udowadniał, że tylko wspólna praca przyniesie efekty. Mocno wierzył w odzyskanie autokefalii kościelnej, która uwolniłaby Bułgarów od podłych greckich duchownych. Wszystkie jego marzenia i cele spełniły się. 
Budziciele mocno wpływali na lud i napędzali proces odrodzenia narodowego. Grigor Pyrliczew jest jednym z najwybitniejszych działaczy bułgarskiego odrodzenia, który pokrzepił i zjednoczył wielu ludzi, przede wszystkim jednak wpłynął na wychowanie młodego pokolenia bułgarskich patriotów.

\section{Summary}

Parlichev had a successful and big impact on the Bulgarian society. He helped people understand their national identity, encouraged sending children to Bulgarian schools and learning the Bulgarian language. He proved the beauty and usefulness of this language while pointing out the hardships associated with learning Greek. He helped Bulgarians open their eyes to Greek offenses, to the evil deeds of Greek clergy. He uplifted his Bulgarian brothers. National revivalists are believed to have heavily influenced the Bulgarian society and that also applies to Grigor Parlichev.

\section{Literatura}

Детрез, Р. „Турците със сила, гърците с книга“. Митът за двойното робство. In: История. Митология. Политика. Sofia, 2010. Tłum. К. Грозев, Н. Гьльбова. Dostęp z: http://librev.com/index.php/discussion-bulgariapublisher/1624-2012-06-01-20-04-19 (2020-03-03).

Пърличев, Г. Григор Пърличев. Избрани произведения. София, 1980. Dostęp z: http://www.promacedonia.org/gps/pyrlichev_3_publitsistika.pdf (2020-02-27).

Темелски, Х. От фермана до схизмата (Или как Българската православна църква получи пълна независимост). In: Българската църква през вековете. Научна сесия по случай 1130 години от учредяването на Българската църква и 130 години от създаването на Българската екзархия. Съст. П. Петков. София, 2003.

Czekalski, T. Butgaria. Warszawa: Wydawnictwo Trio, 2010.

Dąbek-Wirgowa, T. Historia literatury butgarskiej. Warszawa: Zakład Narodowy im. Ossolińskich 1980.

Drzewiecka, E. Od przyjemności do pomyślności, czyli o pożytkach z (bułgarskiego) „oświecenia”. In: Solak, E., Popiołek, B., Todorović, B. (eds.) Mate przyjemności: katalog stowiański. Kraków, 2016, s. 227-238. Dostęp z: https://www.researchgate.net/publication/325193036_Od_przyjemnosci_do_po myslnosci_czyli_o_pozytkach_z_bulgarskiego_oswiecenia_From_pleasure_to_ 
prosperity_or_what_are_the_benefits_of_the_Bulgarian_enlightenment (202003-07).

Floryan, W. (ed.) Dzieje literatur europejskich. Tom 3, cz. 2. Warszawa: PWN, 1991.

Simeonova-Konach, G. Z dziejów bułgarskiego ruchu kościelnego w XIX wieku. Narracje i fakty (Autokefalia. Unici. Konstantynopolitańskie konteksty polityczne). Rocznik Teologiczny. 2010 (52/1-2), s. 257-278. Dostęp z: http://bazhum.muzhp.pl/media//files/Rocznik_Teologiczny/Rocznik_Teologicz ny-r2010-t52-n1_2/Rocznik_Teologiczny-r2010-t52-n1_2-s257278/Rocznik_Teologiczny-r2010-t52-n1_2-s257-278.pdf (2020-03-05).

Stawowy-Kawka, I. Historia Macedonii. Wrocław: Ossolineum, 2000. 